\title{
Dolops carvalboi as a vector of Epistylis sp. between cultivated and wild specimens of Oreochromis niloticus in Brazil
}

\author{
Dolops carvalhoi como vetor de Epistylis sp. entre espécimes cultivados e silvestres de \\ Oreochromis niloticus no Brasil
}

\author{
Cibele Diogo Pagliarini ${ }^{1 *}$; Lidiane Franceschini ${ }^{2}$; Cristiéle da Silva Ribeiro ${ }^{3}$; Rosilene Luciana Delariva ${ }^{4}$; \\ João Paulo de Arruda Amorim ${ }^{4}$; Igor Paiva Ramos ${ }^{1}$
}

\begin{abstract}
${ }^{1}$ Laboratório de Ecologia de Peixes, Departamento de Biologia e Zootecnia, Faculdade de Engenharia de Ilha Solteira, Universidade Estadual Paulista - UNESP, Ilha Solteira, SP, Brasil

${ }^{2}$ Laboratório de Parasitologia de Animais Silvestres, Departamento de Parasitologia, Instituto de Biociências de Botucatu, Universidade Estadual Paulista - UNESP, Botucatu, SP, Brasil

${ }^{3}$ Laboratório de Fisiologia Animal, Departamento de Biologia e Zootecnia, Faculdade de Engenharia de Ilha Solteira, Universidade Estadual Paulista - UNESP, Ilha Solteira, SP, Brasil

${ }^{4}$ Centro de Ciências Biológicas e da Saúde, Universidade Estadual do Oeste do Paraná - UNIOESTE, Cascavel, PR, Brasil
\end{abstract}

Received September 25, 2018

Accepted November 27, 2018

\begin{abstract}
Epistyliasis has been characterized as an emergent disease which has a great impact on fish farms, especially on Oreochromis niloticus production systems. Although epidemiological important, information about the dispersion of these parasites and their mechanical vectors is scarce. The present study reported the cooccurrence of Epistylis sp. as an epibiont of Dolops carvalhoi, a parasitic crustacean of cultivated/wild specimens (from accidental release) of O. niloticus from a cage fish farm area in the Ilha Solteira Reservoir, Grande River, SP, Brazil. The co-occurrence of Epistylis sp. and D. carvalhoi, and their epibiont relationship registered in this study suppose that the Epistylis may use the crustaceans for dispersion and as mechanical vectors for the dissemination of diseases in wild and cultivated hosts. Moreover, exchange of parasites between wild and cultivated hosts is possible, considering both organisms (protozoan and argulid). Furthermore, the results of the present study demonstrate the need to monitor the areas adjacent to cage fish farms as a preventive measure for the dispersion of pathogens. This is the first report of epibiosis between Epistylis sp. and argulid parasites of cultivated and wild $O$. niloticus, contributing to knowledge about host-parasite specificity, geographical distribution, dispersion of etiological agents and epidemiology in aquaculture.
\end{abstract}

Keywords: Ciliates peritrichs, cage fish farm, epistyliasis, epibiont, mechanical vector.

\section{Resumo}

Epistilíase tem sido caracterizada como uma doença emergente de grande impacto nas pisciculturas, especialmente em sistemas de produção de Oreochromis niloticus. Embora seja importante epidemiologicamente, informaçóes sobre a dispersão desses parasitas e seus vetores mecânicos são escassos. O presente estudo relata a coocorrência de Epistylis sp. como um epibionte de Dolops carvalhoi, um crustáceo parasita de espécimes cultivados e silvestres (de escapes acidentais) de $O$. niloticus em área de piscicultura de tanques-rede no reservatório de Ilha Solteira, Rio Grande, SP, Brasil. A coocorrência de Epistylis sp. e D. carvalhoi, e sua relação epibionte registrada neste estudo, supóem que Epistylis sp. possa utilizar os crustáceos para dispersão e como vetores mecânicos para a disseminação de doenças em hospedeiros silvestres e cultivados. Além disso, a troca de parasitas entre hospedeiros silvestres e cultivados é possível, considerando ambos os organismos (protozoários e argulídeos). Os resultados deste estudo, também demonstram a necessidade de monitorar as áreas adjacentes às pisciculturas como medida preventiva para a dispersão de patógenos. Este é o primeiro relato de epibiose entre Epistylis sp. e parasitas argulídeos de O. niloticus cultivados e silvestres, contribuindo para o conhecimento da especificidade parasitária do hospedeiro, distribuição geográfica, dispersão de agentes etiológicos e epidemiologia na aquicultura.

Palavras-chave: Ciliados peritríquios, piscicultura em tanques-rede, epistilíase, epibionte, vetor mecânico.

\footnotetext{
*Corresponding author: Cibele Diogo Pagliarini. Departamento de Biologia e Zootecnia, Faculdade de Engenharia de Ilha Solteira, Universidade Estadual Paulista - UNESP, Rua Monção, 226, CEP 15385-000, Ilha Solteira, SP, Brasil. e-mail: cibelepagliarini3@gmail.com
} 
Sessile peritrich ciliates can colonize living substrates in an ecological relationship known as epibiosis. They are commonly found attached to a variety of organisms from marine, estuarine and freshwater environments such as plants, zooplanktonic invertebrates, larval stages of aquatic insects, fish, amphibians, reptiles, aquatic mollusks and crustaceans (free-living and parasites) (UTZ, 2007; PÁDUA et al., 2013; KÜHNER et al., 2016 and references therein).

The genus Epistylis Ehrenberg, 1830 (Ciliophora, Epistylididae) contains more than 120 described species of peritrichs. Besides being epibionts, these are emerging parasites that are commonly recorded in wild and cultivated fish (EIRAS et al., 2012; ZAGO et al., 2014; VALLADÁO et al., 2014; KÜHNER et al., 2016). Although important from an epidemiological perspective, informations about the dispersion of these parasites and their potential mechanical vectors in aquaculture system are scarce, there being a recent report for Megaleporinus obtusidens farmed in fish ponds from Southeast Brazil (PALA et al., 2018). In Brazil, epistyliasis has been characterized as an emergent disease which has a great impact on fish farms (MARTINS et al., 2015), especially on Nile tilapia Oreochromis niloticus (Linnaeus, 1758) production systems.

Oreochromis niloticus is one of the most widely cultivated fish species, and Brazil is the fourth largest global producer (PEIXEBR, 2018). Knowledge of the effects caused by the intensive fish farming may have on the environment is fundamental for the sustainability of aquatic ecosystems and for maintaining the efficiency of the production system, including sanitary management and prophylactic measures. While $O$. niloticus has been the subject of many studies due to its large commercial production and human consumption, some points remain unexplained, such as the environmental effects caused by the accidental release of individuals from farming systems, including host-parasite interactions and epidemiological aspects involving cultivated and wild host specimens.

The present study reported the occurrence of Epistylis sp. as an epibiont of Dolops carvalhoi Lemos de Castro (1949) (Crustacea, Argulidae), a parasitic crustacean of cultivated and wild specimens (from accidental release) of $O$. niloticus from a cage fish farm area in the Ilha Solteira Reservoir on the Grande River in the state of São Paulo, Brazil.

The collections were performed in a cage fish farm which breeds Nile tilapia (O. niloticus), located in the municipality of Santa Clara D'Oeste in the state of São Paulo, in the Can-Can distributary of the Ilha Solteira Reservoir, in the Grande River $\left(50^{\circ} 55^{\prime} 59.65^{\prime \prime} \mathrm{W}\right.$ and $20^{\circ} 02^{\prime} 30.54$ 'S). The region is considered the fifth largest hub of freshwater fish production in Brazil and has several cage fish farms (IBGE, 2016) and favorable conditions for assessing the environmental influences of this activity.

Two samples were taken, one during the rainy period (in December 2016) and one during the dry period (in July 2017). A total of 100 specimens of $O$. niloticus were collected during each sample, of which 50 specimens were taken from the cage fish farm (cultivated specimens) and 50 from the wild (from accidental releases), in area adjacent to the fish farm. Cultivated specimens were taken with the aid of a dip net, and wild specimens were collected using casting nets (meshes with $100 \mathrm{~mm}$ rate between nodes), in accordance to the License for the Collection of Zoological
Material (SISBio \# 56809-1) and the Ethics Committee on use of animals (CEUA -protocol \#01/2017).

The surfaces of the bodies of the fish were analyzed to search for ectoparasites and the presence of external macroscopic lesions. The specimens of $O$. niloticus were submitted to skin scraping to collect the mucus on slides, and the fresh slides were analyzed with the aid of an optic microscope to detect ciliates (EIRAS et al., 2006). The crustaceans were fixed and preserved in ethanol $70^{\circ}$, posteriorly mounted in Hoyer's medium, and photographed using a computerized image analysis system coupled to an optic microscope with differential interference contrast (DIC), and another linked to a microscope stereoscope (Leica Application Suite, V3; Leica Microsystems, Wetzlar, Germany).

Prevalence ( $\mathrm{P}=$ expressed in percentage), mean intensity of infestation (MII) and mean abundance (MA) was calculated according to Bush et al. (1997). The mean intensity of infestation and mean abundance of $D$. carvalhoi parasitizing $O$. niloticus are expressed as means, followed by standard error and range (minimum - maximum) in parentheses. The criteria for characterizing the intensity of parasitism by Epistylis sp. in the analyzed fish was determined by the scores from 1 to 4 (PÁDUA et al., 2013), based on the presence and number of layers of zooids. Vouchers of the crustaceans associated with Epistylis sp. (epibiosis) were deposited in the Helminthological Collection of the Institute of Biosciences (CHIBB 8517-8520), São Paulo State University (UNESP), in the municipal region of Botucatu, in the state of São Paulo, Brazil.

Based on optic microscopy analysis, the morphology of the fresh zooids found in D. carvalhoi and on the skin of wild and cultivated $O$. niloticus corresponded to peritrichs belonging to Epistylis (Figure 1A-D). The zooids in both host conditions had a conical to elongated format, peduncle dichotomously branched and noncontractile (Figure 1C and D), macronucleus transverse and $\mathrm{C}$-shaped, presence of one contractile vacuole in the apical portion of the zooid and the cytoplasm with numerous food vacuoles.

The identification of branchiurans corresponded to that proposed by Castro (1949) and Thatcher (2006). The specimens analyzed had a simple first maxilla, armed with claws; the basal plate of the second maxilla armed with three teeth (Figure 1C), abdominal lobes of medium length, compound eyes, the ventral surface of the carapace without spines, and the dorsal surface of the carapace with starry pigmented spots, with more intense pigmentation at the margin of the carapace.

The same prevalence of ciliates was observed on the skin of analyzed cultivated and wild fish $(\mathrm{P}=76 \%)$. Of the cultivated parasitized fish (38 specimens), 7.9\% were classified as score 4, in which the hosts had multifocal colonies with larger dimensions which were easily seen with a naked eye, and the rest were classified as between score 2 and 3, with moderate infection. Among the wild parasitized specimens (38 specimens), 5.3\% were classified as score 4, and also had multifocal colonies of Epistylis sp., with larger dimensions and multiples lesions on the skin; $7.9 \%$ were within score 3, with small colonies observed with a naked eye, and the rest were score 2 , with large amounts of zooids organized into colonies, observed with the aid of a microscope (PÁDUA et al., 2013).

In terms of infestation by D. carvalhoi, a total of 14 specimens (males and females) were found. Only one specimen of cultivated 

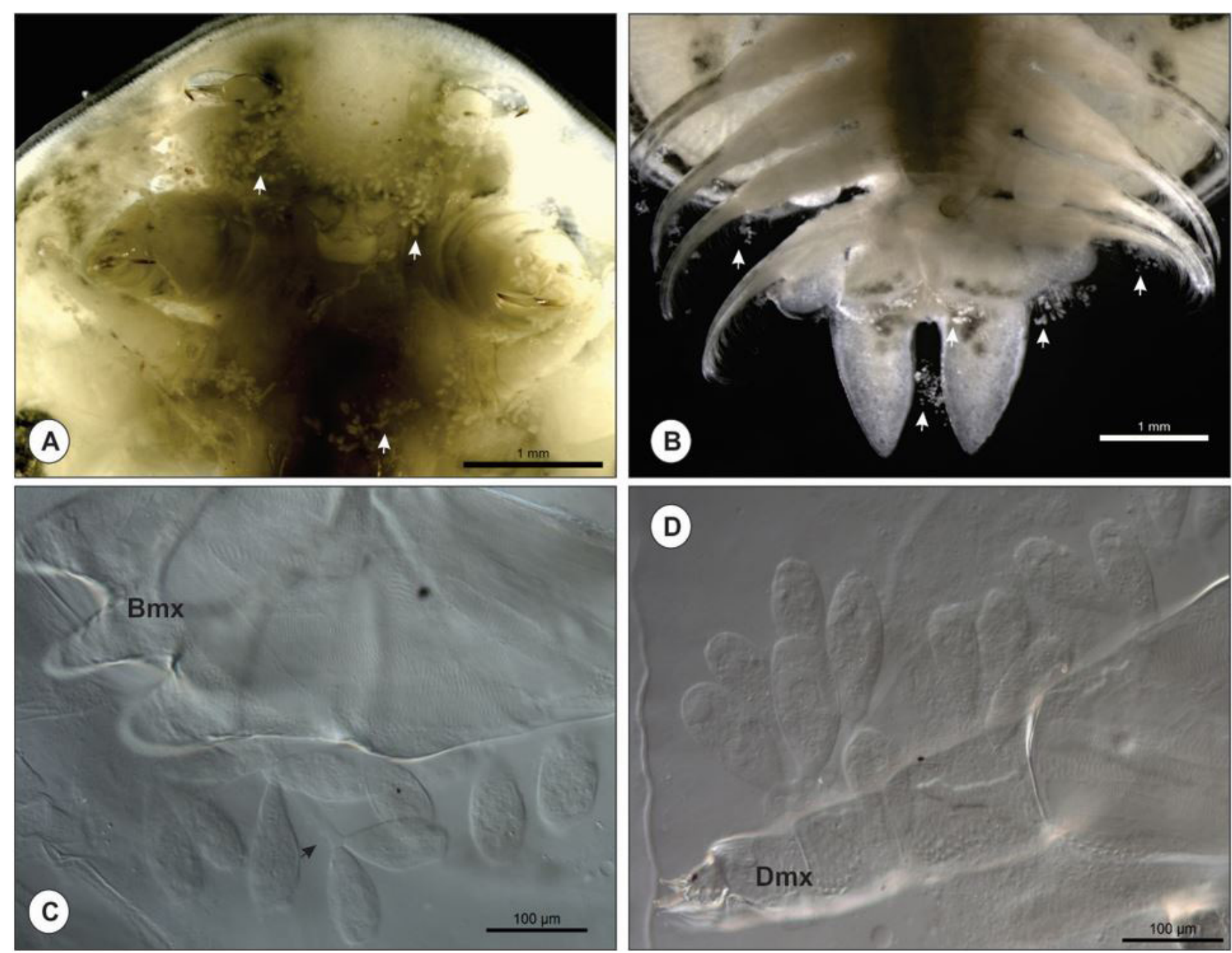

Figure 1. Zooids of epibiont Epistylis sp. (Ciliophora, Epistylididae) attached to Dolops carvalhoi (Crustacea, Branchiura), an ectoparasite of cultivated and wild Oreochromis niloticus (Perciformes, Cichlidae) from Ilha Solteira Reservoir, Grande River, in the state of São Paulo, Brazil. (A-B) Colonies of Epistylis sp. adhered to the body surface of D. carvalhoi (white arrows) (photographed with aid of stereomicroscope); (C-D) Photomicrographs of zooids of Epistylis sp. (C) at the basal plate (Bmx) (detail of a dichotomously branched peduncle - black arrow), and (D) at the distal end of the second maxilla (Dmx) of D. carvalhoi.

O. niloticus $(\mathrm{P}=2 \%)$ was parasitized by a single crustacean, while $10 \%$ of wild $O$. niloticus were parasitized by branchiurans $(\mathrm{MII}=2.6 \pm 0.98[1-5] ; \mathrm{AM}=0.26 \pm 0.14$ [0-5]). In three wild $O$. niloticus was observed the co-occurrence of $D$. carvalhoi associated with Epistylis sp. (epibiosis) and Epistylis sp. parasitizing the skin of hosts classified as scores 3 and 4 (PÁDUA et al., 2013). Colonies of zooids were observed in all the crustaceans collected from both cultivated and wild $O$. niloticus.

Under intensive cage fish farming conditions there is an increased discharge of nutrients into the aquatic environment (MONTANHINI \& OSTRENSKY, 2015), which can lead to the proliferation of some parasites including ciliate protozoans (PÁDUA et al., 2016). The occurrence of epistyliasis in fish farms can be associated with low water quality, low oxygen concentration and improper handling such as high stock densities and incorrect feeding practices (EIRAS et al., 2012; PÁDUA et al., 2013; MARTINS et al., 2015; PÁDUA et al., 2016). Although Epistylis does not directly invade the host cells, its can cause injury to the integument of fish, characterized by the presence of epithelial hyperplasia and hypertrophy, possibly caused by constant contact with the fish skin (VALLADÃO et al., 2014). Additionally, can occur secondary infection associated with the presence of bacteria on the peduncle, culminating in mortality and pathological changes (PÁDUA et al., 2013; MARTINS et al., 2015; PÁDUA et al., 2016), causing major losses in South American aquaculture.

Epibiosis studies on sessile peritrichs associated with crustacean parasites are scarce. Epistylis spp. have been described colonizing others parasitic crustaceans as Lernaea bamimiana (Hartman, 1870), Lernaea cyprinacea Linnaeus, 1758 (Copepoda, Ergasilidae) and Dolops ranarum (Stuhlmann, 1891) (Branchiura, Argulidae) from various fish hosts in South Africa (VAN AS \& VILJOEN, 1984; FERNANDEZ-LEBORANS \& TATO-PORTO, 2000). In Brazil, an epibiont relation was described between Epistylis sp. and some ectoparasitic crustaceans such as: Amplexibranchius 
bryconis Thatcher \& Paredes, 1985 (Copepoda, Ergasilidae), in Prochilodus lineatus (Valenciennes, 1837) (Characiformes, Prochilodontidae) from the Peixe's River (ABDALLAH et al., 2011); Ergasilus chelangulatus Thatcher and Brasil-Sato, 2008 (Copepoda, Ergasilidae), in Pimelodus maculatus Lacépède, 1803 (Siluriformes, Pimelodidae) from the Veados River (AZEVEDO et al., 2014); Argulus sp. (Crustacea, Branchiura), in Hoplias aimara (Valenciennes, 1847) (Characiformes, Erythrinidae) from the Amazon Basin (CORREAA et al., 2016). However, there is few information about epibiont associations involving cultivated species of vertebrate hosts (PALA et al., 2018).

Thirteen species are known to belong to Dolops most of which are endemic to the Neotropical region (South and Central America), except for two species found on other continents - Dolops ranarum, which is exclusively from Africa, and D. tasmanianus Fryer, 1969, which is found only in Tasmania (NEETHLING \& AVENANT-OLDEWAGE, 2016; WoRMS, 2018). The occurrence of $D$. carvalhoi is recorded in 12 species of wild and cultivated Brazilian freshwater fishes (LUQUE et al., 2013), but there are few records of epibiont relationships involving peritrichs and parasitic argulids (CÔRREA et al., 2016; PALA et al., 2018).

Given the form of food intake and oral apparatus of the argulids (in Dolops, the first maxilla is prehensile and terminates in strong claws), their occurrence can cause an inflammatory reaction in the vicinity of the bite, changes to blood parameters and ulcerative lesions, favoring the development of secondary infections due to the penetration of fungi and bacteria (TAVARES-DIAS et al., 2007; PAVANELLI et al., 2008). They can also be associated with the dissemination of viral diseases in fish (OVERSTREET et al., 2009).

The ability of Epistylis spp. to colonize free-living (FERNANDEZLEBORANS \& TATO-PORTO, 2000; AZEVEDO et al., 2014) and parasitic crustaceans (VAN AS \& VILJOEN, 1984; FERNANDEZLEBORANS \& TATO-PORTO, 2000; CORRÊA et al., 2016), allows the crustaceans to act as host reservoirs for these peritrichs, while Epistylis may use them for dispersion and as potential mechanical vectors for the dissemination of diseases in wild and cultivated hosts (EIRAS et al., 2012; PÁDUA et al., 2013; MARTINS et al., 2015). The co-occurrence of Epistylis sp. and D. carvalhoi, and their epibiont relationship registered in this study suppose that the exchange of parasites between wild and cultivated hosts is possible, considering both organisms (protozoan and argulid).

The development of aquaculture systems with proper handling results in fewer effects on water quality and prevent problems related to parasitism, and consequently economic losses and environmental damage. This is the first report of epibiosis between Epistylis sp. and argulid parasites of cultivated and wild $O$. niloticus, contributing to knowledge about host-parasite specificity, geographical distribution, dispersion of etiological agents and epidemiology in aquaculture. Furthermore, the results of the present study demonstrate the need to monitor the areas adjacent to fish farms as a preventive measure for the dispersion of pathogens.

\section{Acknowledgements}

We are grateful to Letícia de Oliveira Manoel, José Daniel Soler Garves and Aymar Orlandi Neto for logistical support in the collection of hosts and taxonomic suggestions. We also thank Puro Peixe Fishery for permission to do the work, the Laboratório de Parasitologia de Animais Silvestres (LAPAS) and Faculdade de Engenharia de Ilha Solteira (FEIS), São Paulo State University - UNESP for the use of laboratory facilities and logistics. The authors would like to thank CAPES (Coordination for the Improvement of Higher Education Personnel), FAPESP (São Paulo Research Foundation) and CNPq (National Council for Scientific and Technological Development) for financial and scientific support (CNPq 443103/2014-3), and the post-graduate scholarships granted to C.D.P. (FAPESP process 2016/23468-6), L.F (CAPES/PNPD 17/2016).

\section{References}

Abdallah VD, Azevedo RKD, Silva RJD. First record of an epibiont protozoan Epistylis sp. (Ciliophora, Peritrichia) attached to Amplexibranchius bryconis Thatcher \& Paredes, 1985 (Copepoda, Ergasilidae) from Peixe’s River, state of São Paulo, Brazil. Crustaceana 2011; 84(9): 1139-1144. http://dx.doi.org/10.1163/001121611X584352.

Azevedo RK, Brandão H, Abdallah VD, Silva RJ. First record of an epibiont protozoan Epistylis sp. (Ciliophora, Peritrichia) attached to Ergasilus chelangulatus (Ergasilidae) in Brazil. Braz J Biol 2014; 74(2): 460-463. http://dx.doi.org/10.1590/1519-6984.10112. PMid:25166331.

Bush AO, Lafferty KD, Lotz JM, Shostak AW. Parasitology meets ecology on its own terms: Margolis et al. revisited. J Parasitol 1997; 83(4): 575 583. http://dx.doi.org/10.2307/3284227. PMid:9267395.

Castro AL. Contribuição ao conhecimento dos crustáceos argulídeos do Brasil (Branchiura: Argulidae) com descrição de uma nova espécie. Bol Mus Nac 1949; 93: 1-8.

Corrêa LL, Oliveira MSB, Prestes L, Tavares-Dias M. First Record in Brazil of Epistylis sp. (Ciliophora) Adhered to Argulus sp. (Argulidae), a Parasite of Hoplias aimara (Eritrhinidae). Nat Resour 2016; 7: 331-336.

Eiras JC, Takemoto RM, Pavanelli GC. Métodos de estudo e técnicas laboratoriais em parasitologia de peixes. 2. ed. Maringá: Eduem; 2006.

Eiras JC, Takemoto RM, Pavanelli GC, Luque JL. Checklist of Protozoan parasites of fishes from Brazil. Zootaxa 2012; 3221(3221): 1-25.

Fernandez-Leborans G, Tato-Porto ML. A Review of the Species of Protozoan Epibionts on Crustaceans. I. Peritrich Ciliates. Crustaceana 2000; 73(6): 643-683. http://dx.doi.org/10.1163/156854000504705.

Instituto Brasileiro de Geografia e Estatística - IBGE. Produção da pecuária municipal 2015. Epi info [online]. Rio de Janeiro: IBGE; 2016 [cited 2018 Aug 28] Available from: https://biblioteca.ibge.gov.br/visualizacao/ periodicos/84/ppm_2015_v43_br.pdf.

Kühner S, Simão TLL, Safi LSL, Gazulha FB, Eizirik E, Utz LRP. Epistylis portoalegrensis n. sp. (Ciliophora, Peritrichia): A New Freshwater Ciliate Species from Southern Brazil. J Eukaryot Microbiol 2016; 63(1): 93-99. http://dx.doi.org/10.1111/jeu.12252. PMid:26198754.

Luque JL, Vieira FM, Takemoto RM, Pavanelli GC, Eiras JC. Checklist of Crustacea parasitizing fishes from Brazil. Check List 2013; 9(6): 14491470. http://dx.doi.org/10.15560/9.6.1449.

Martins ML, Cardoso L, Marchiori N, Benites de Pádua S. Protozoan infections in farmed fish from Brazil: diagnosis and pathogenesis. Rev Bras Parasitol Vet 2015; 24(1): 1-20. http://dx.doi.org/10.1590/S198429612015013 . PMid:25909248. 
Montanhini R No, Ostrensky A. Nutrient load estimation in the waste of Nile tilapia Oreochromis niloticus (L.) reared in cages in tropical climate conditions. Aquacult Res 2015; 46(6): 1309-1322. http://dx.doi. org/10.1111/are.12280.

Neethling LAM, Avenant-Oldewage A. Branchiura - A compendium of the geographical distribution and a summary of their biology. Crustaceana 2016; 89(11-12): 1243-1446. http://dx.doi.org/10.1163/1568540300003597.

Overstreet RM, Jovonovich J, Ma H. Parasitic crustaceans as vectors of viruses, with an emphasis on three penaeid viruses. Integr Comp Biol2009; 49(2): 127-141. http://dx.doi.org/10.1093/icb/icp033. PMid:21669853.

Pádua SB, Ishikawa MM, Ventura AS, Jerônimo GT, Martins ML, Tavares LE. Brazilian catfish parasitized by Epistylis sp. (Ciliophora, Epistylididae), with description of parasite intensity score. Parasitol Res 2013; 112(1): 443-446. http://dx.doi.org/10.1007/s00436-012-3069-5. PMid:22890898.

Pádua SB, Martins ML, Valladão GMR, Utz L, Zara FJ, Ishikawa $\mathrm{MM}$, et al. Host-parasite relationship during Epistylis sp. (Ciliophora: Epistylididae) infestation in farmed cichlid and pimelodid fish. Pesqui Agropecu Bras 2016; 51(5): 520-526. http://dx.doi.org/10.1590/S0100204X2016000500012.

Pala G, Farias THV, Alves LO, Pilarski F, Hoppe EGL. Association of Epistylis spp. (Ciliophora: Peritrichia) with parasitic crustaceans in farmed piava Megaleporinus obtusidens (Characiformes: Anostomidae). Rev Bras Parasitol Vet 2018; 27(3): 348-353. PMid:30183996.

Pavanelli GC, Eiras JC, Takemoto RM. Doenças de peixes: profilaxia, diagnóstico e tratamento. 3. ed. Maringá: Eduem; 2008.
Peixe BR. Anuário Peixe BR da Piscicultura 2018. Epi info [online]. São Paulo: Peixe Br; 2018 [cited 2018 Aug 28]. Available from: https://www. peixebr.com.br/anuario2018/.

Tavares-Dias M, Moraes FR, Onaka EM, Rezende PCB. Changes in blood parameters of hybrid tambacu fish parasitized by Dolops carvalhoi (Crustacea, Branchiura), a fish louse. Vet Arh 2007; 77(4): 355-363.

Thatcher VE. Amazon Fish Parasites. 2nd ed. Moscow: Pensoft; 2006.

Utz LRP. First record of Epistylis plicatilis (Ciliophora: Peritrichia) attached to Pomacea canaliculata (Mollusca: Gastropoda) in Southern Brazil. Zootaxa 2007; 1454(1): 49-57.

Valladão GMR, Levy-Pereira N, Viadanna PHO, Gallani SU, Farias THV, Pilarski F. Haematology and histopathology of Nile tilapia parasitised by Epistylis sp., an emerging pathogen in South America. Bull Eur Assoc Fish Pathol 2014; 35(1): 14-20.

Van As JG, Viljoen S. A taxonomic study of sessile peritrichs (Ciliophora: Peritricha) associated with crustacean fish ectoparasites in South Africa, South African. S Afr J Zool 1984; 19(4): 275-279. http://dx.doi.org/10 .1080/02541858.1984.11447893.

World Register of Marine Species - WoRMS. Epi info [online]. 2018 [cited 2018 Aug 28]. Available from: http://www.marinespecies.org/ aphia.php? $\mathrm{p}=$ taxdetails\&id=347079

Zago AC, Franceschini L, Garcia F, Schalch SHC, Gozi KS, Silva RJ. Ectoparasites of Nile tilapia (Oreochromis niloticus) in cage farming in a hydroelectric reservoir in Brazil. Rev Bras Parasitol Vet 2014; 23(2): 171 178. http://dx.doi.org/10.1590/S1984-29612014041. PMid:25054495. 